\title{
USING PALLETISED WORK-HOLDING TO EMULATE 5-AXIS MACHINING OF AEROSPACE COMPONENTS IN THE DEVELOPING WORLD
}

\author{
G.A. Oosthuizen ${ }^{1}$, H.J. Joubert ${ }^{2}$ and N.F. Treurnicht ${ }^{3}$ \\ 1, 2, ${ }^{3}$ Department of Industrial Engineering \\ University of Stellenbosch, South Africa \\ ${ }^{1}$ tiaan@sun.ac.za, ${ }^{2}$ h2j@sun.ac.za, ${ }^{3}$ nicotr@sun.ac.za
}

\begin{abstract}
This paper proposes the application of precision pallet technology, together with common 3 -axis milling, to machine certain complex aerospace components that are normally 5-axis machined. In this approach a set of different customised precision pallets are used to present each complex plane to the 3-axis machine as a series of horizontal planes for machining. After machining one surface, the pallet is exchanged for another that has been pre-setup in machining time. Trials confirm the viability of the approach, with capital recovery in less than a year.
\end{abstract}

\section{OPSOMMING}

Hierdie artikel stel die aanwending van presisiepallettegnologie, saam met gewone 3-as frees, voor om komplekse lug- en ruimtevaartkomponente te vervaardig. Die gebruiklike metode om hierdie komponente te vervaardig vereis 5 -as masjinering. In die voorgestelde benadering word 'n stel verskillende pasgemaakte presisiepalette gebruik om elke komplekse vlak as ' $n$ reeks horisontale vlakke te posisioneer vir masjinering. Die gevolg is dat eenvoudige en vinnige vlakfrees voldoende is. Nadat een vlak gemasjineer is, word die pallet vervang met 'n ander wat vooraf opgestel is gedurende masjineringstyd. Toetse bevestig die lewensvatbaarheid, met kapitaaldelging in minder as ' $n$ jaar.

\footnotetext{
${ }^{1,2}$ The authors were enrolled for an MSc degree in the Department of Industrial Engineering, University of Stellenbosch.

${ }^{3}$ Corresponding author
} 


\section{INTRODUCTION}

Many developing countries, in this case South Africa, have a significant technology base in certain fields. For projects such as a space observation telescope, satellite development and launches, and new nuclear power generation concepts, an advanced manufacturing capability is a prerequisite. A common factor among developing nations is that their monetary exchange rate is favourable for exports rather than for imports $(€ 1=12$ SARand, Feb 2009). Being fully imported, advanced machine tools therefore represent a large investment in terms of local currency. According to Byrne et al. [1], machine tool developers are expected to concentrate not on maximum speeds and acceleration of machine axes, but on other aspects of non-productive time, such as the set-up time of machines. This includes work in the area of machine accuracy and flexibility.

The objective of this study is to address the scarcity of simultaneous 5-axis machines by exploring the use of precision palletised work-holding, in order to emulate 5-axis machining on a 3 -axis machine for flat surfaces. To provide a suitable context, the subject is introduced from the perspective of flexible manufacturing.

The company where the study of this approach was conducted manufactures short-run components, prototypes, and tools on demand to typical aerospace specifications. The 5axis CNC machines are mostly fully occupied for 24-hour shifts, 7 days a week, while the 3axis machines have reserve capacity.

\section{BACKGROUND}

Nagarjunaa et al. [2] mentioned that manufacturing industries are rapidly changing from economies of scale to economies of scope. These industries are characterised by short product life cycles and increased product variety, which is similar to the situation at the company where the concept was tested. This implies a need to improve the efficiency of job shops while still maintaining their flexibility. An increase in the speed of manufacturing, together with minimised secondary times, and greater process stability and machining quality, continuously increases production efficiency [3]. A flexible manufacturing system (FMS) can be defined as an integrated computer-controlled configuration of numerical control machine tools, as well as a work-holding and material handling system designed to manufacture simultaneously a low to medium volume of a wide variety of high quality products at low cost [4]. The proposed pallet work-holding system allows for different operations on a standardised pallet chuck. This significantly reduces changeover and setup times, making the process adaptable and flexible. All proposed setup adjustments take place outside the milling machine, and within the machining cycle time of other parts undergoing similar machining operations. This is the case for 3 -axis machining. Should 5-axis machining be available, changeover and setup times can be reduced significantly.

\subsection{Flexible work-holding}

The company manufactures on a strictly make-to-order basis. Therefore the work-holding method should cater for a wide range of different part sizes and cutting strategies. As mentioned, extreme flexibility is required of the work-holding technique. Of the ten desirable characteristics of work holders examined by Fellers et al. [5], holding, supporting, part location, and tool approach accessibility are applicable.

Figure 1 [6] shows the different flexible work-holding strategies, and indicates the manually assembled work-holding strategy used by this company. 


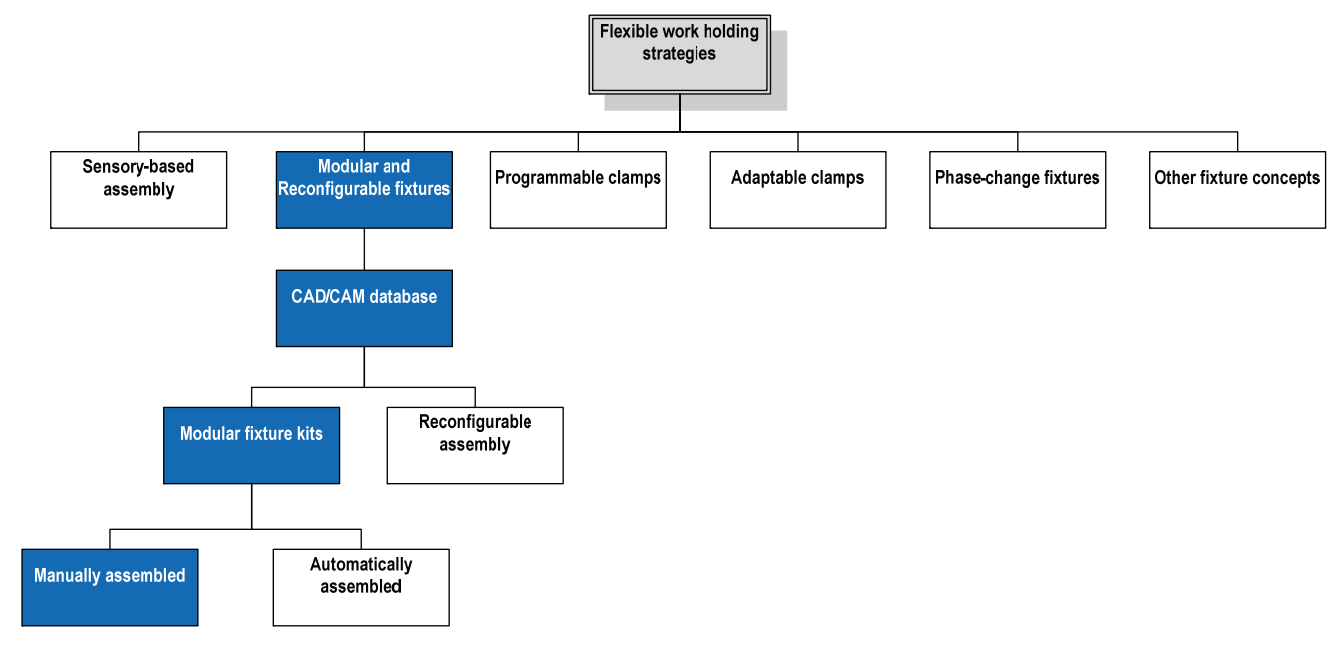

Figure 1: Flexible work-holding strategies [6]

Choi et al. [7] mentioned that if the part could be magnetically suspended in the air, all sides could be machined without changing the set-up. The result would be a single machine set-up that is often called 'complete machining'. The integration of various machining processes into one machine tool and six side machining process strategies has transformed the classical process chains into one clamping [1]. In addition, process designs have been further optimised for productivity by introducing parallel processing and hybrid (also known as 'assisted machining') processes, such as laser aided turning.

All these approaches have one main goal: to reduce the non-value-adding processing times due to transportation and part handling. This is usually accompanied by an elimination of re-clamping operations, which has positive effects on the accuracy of parts [8].

\subsection{Machine flexibility}

Machine flexibility is the fundamental building block of the other manufacturing flexibilities. As machine flexibility increases, a machine tends to be capable of performing a larger number of operations, as suggested by Koste and Malhotra [9]. A higher level of flexibilities of product mix, process, operation, and routing are the resulting gains [10]. Chen and Chung [11] and Wahab [12] measure machine flexibility as the weighted sum of machine-operation efficiencies.

The various types of machining operation for the relatively complex work-piece are all done on the same machine and, therefore, as mentioned by Groover [13], the setup/changeover time is used as a measure. Setup time is assumed to be inversely proportional to machining flexibility. The proposed pallet system illustrated in figure 2 offers the capability to adapt a given machine to a wide range of production operations and part styles.

The greater the range of operations and part styles, the greater the machining flexibility. The figure clearly illustrates how the different pallets are placed on to the chuck.

\subsection{Production flexibility}

Worldwide, production is facing the need for higher productivity, flexibility, and quality due to the on-going progress of customisation and global competitive markets. Over the last decade, new manufacturing strategies such as high speed and high performance cutting, hard and dry machining, process-integration, complete machining, and new tool materials have either influenced machine tool developments or have been made possible by them 
[14]. As a consequence, productive as well as non-productive times may be drastically reduced. Production flexibility also depends on the machine flexibility of the individual machines [13]. If the company could afford it, investing in standardised pallet chucks (receivers) for each machine would be a way to increase production flexibility. Customised work-holding pallet platforms, which would fit on to standardised chucks of the different machines as illustrated in figure 2, may then be designed for the different complex operations to be performed during manufacture of the parts. This in turn would make all machines more flexible and lead to an increase in swift response to variation in demand (Theodorou [15]).

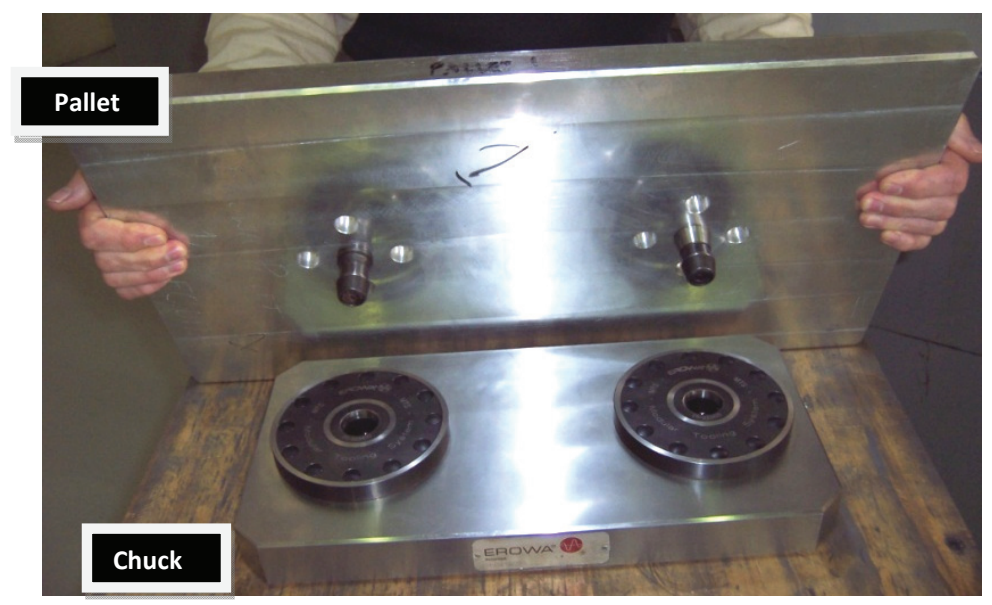

Figure 2: An example of a pallet being mounted on a chuck

\subsection{Flexibility and this study}

Other benefits of flexibility include the increase in machine utilisation, lower manufacturing lead time, and higher labour productivity. In this study, therefore, precision pallet technology is proposed to re-route some of the work that could in the past only be done on the capital-intensive 5-axis machine, to one of the freely available 3-axis machines. Designing processes to work on more generic, freely available machines (3-axis) in this case is an application of production flexibility itself. The method may be compared by means of a time study on the use of successive manual setups, as the alternative of using the 5 -axis machine was not available.

\section{EXPERIMENTAL METHOD}

The research method followed in this study consisted of the mapping of the current process, interviews with technical staff on the current and proposed processes, and a time study. The process was mapped largely through interviews conducted with the technical staff, together with data collection from company records. Such information was used as a benchmark. Interviews throughout the time study served to provide a better understanding of the problem, to identify opportunities or improvements, and to establish a better working relationship with the technical staff.

\subsection{Operations to machine missile wing}

The technology demonstrator suggested by the company is a missile wing. For this component, aerodynamic requirements result in a complex geometry (shown in figure 3 ). The component needs to undergo different machining operations to achieve the required shape. 


\begin{tabular}{|l|l|}
\hline Operation & \\
\hline $\mathbf{1}$ & Pre-operation and clean-up cut \\
\hline $\mathbf{2}$ & Drill set-up and counter sunk holes \\
\hline $\mathbf{3}$ & Mill $3^{\circ}$ angle face \\
\hline $\mathbf{4}$ & Mill $12^{\circ}$ angle face \\
\hline $\mathbf{5}$ & Mill $4^{\circ}$ angle face \\
\hline $\mathbf{6}$ & Cut step, 45 ${ }^{\circ}$ angle and slot \\
\hline $\mathbf{7}$ & Final cut and positioning holes are cut off \\
\hline $\mathbf{8}$ & Handwork on leading edge and corners \\
\hline
\end{tabular}

Figure 3: The required missile wing operations

Similar face milling operations have to be performed at various angles, as shown in figure 4. Using a set of different precision pallets, each customised to the correct angle, each complex plane is presented to the 3 -axis machine as a horizontal plane, resulting in rapid machining and a high quality surface finish. After machining one surface, the pallet is exchanged for another that has been preset. The different cutting operations are indicated in figure 4.

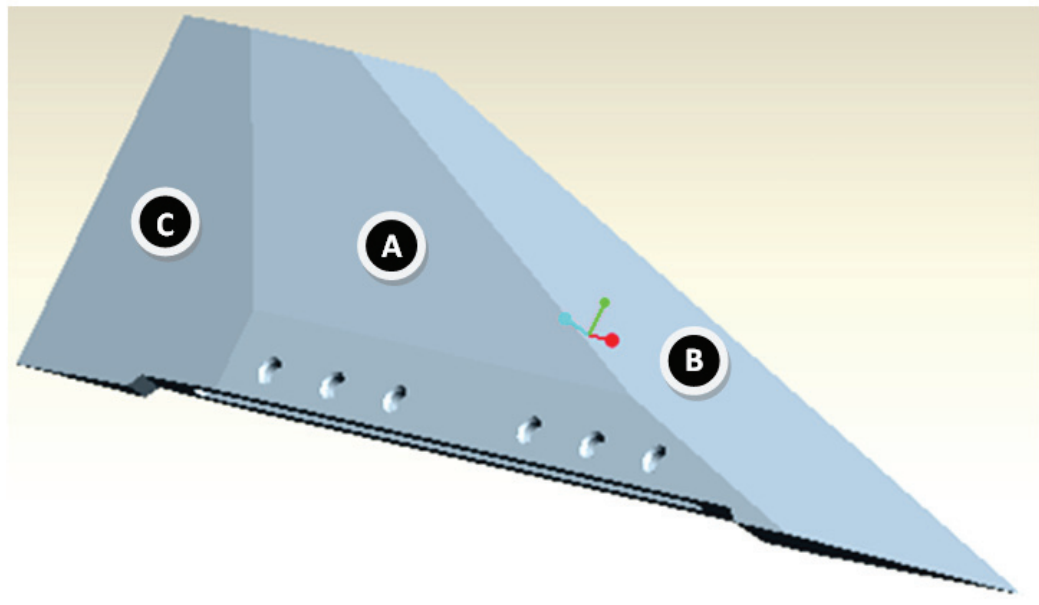

Figure 4: Different milling operations 
Cut $\mathrm{A}$ is a $3^{\circ}$ operation, cut $\mathrm{B}$ a $12^{\circ}$ operation and cut $\mathrm{C}$ a $4^{\circ}$ milling operation. Therefore pallets with different angles have to be manufactured to fit on the chuck base of the pallet system.

\subsection{Current work clamping process}

The established method used by the company to machine the parts was to clamp the workpiece into the vice mounted on the bed of the 3-axis milling machine. When loading a new work piece into the machine, it is important to establish accurate location of the tool prior to the machining cycle. This is usually done with a touch probe or gauge block, which is time-consuming. The time spent on this operation forms a major part of the setup time.

Traditionally, when loading a new work piece on to a machine, accurate location of the blank must be determined prior to the machining cycle. This increases the setup time significantly. Likewise, when moving a work piece from one machine tool to another, it is necessary to reload the partially machined part into a fixture or vice and then establish a datum point from which to continue the machining. This transfer process can be timeconsuming because of the need to re-establish location of the work piece on the second machine tool. This is also a major potential cause of inaccuracy.

\subsection{Proposed pallet process}

A systematic approach to part loading and unloading is available to the machining industry through pallet technology. Although this technique is primarily designed for part loading and unloading, it was proposed in this case to emulate 5-axis machining on a 3-axis machine. Using the chuck and pallet system, a work piece reference location needs to be established only once. Figure 5 illustrates how the different pallets are placed onto the chuck.
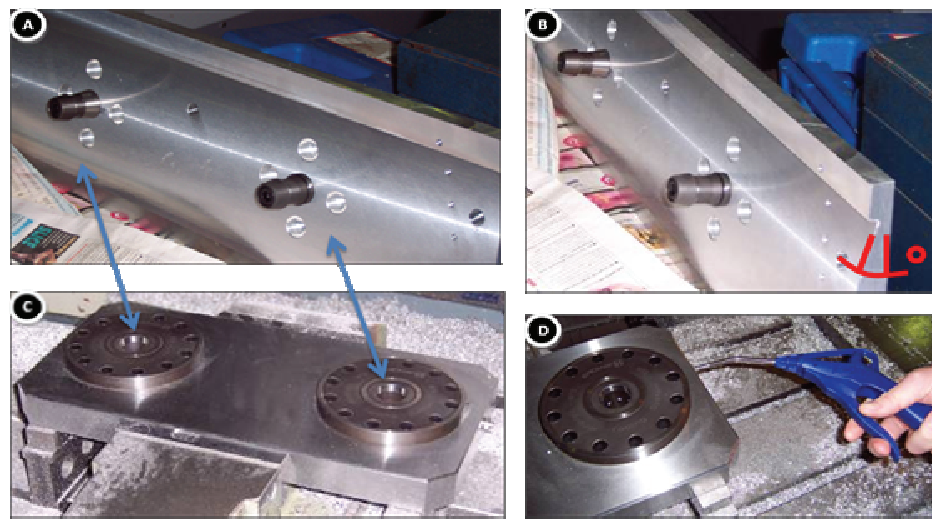

Figure 5: Pallet and chuck system

Figure $5 \mathrm{C}$ shows how the chuck is kept in position by a machine vice. The chuck remains in this position throughout the entire process. All the cuts are made on the chuck or base assembly. Different pallets are machined with the required angles, as shown in figure 5B. These pallets are changed to suit the different cutting processes, as indicated by the arrows in figure 5A. Figure 5D indicates how the pallet is released from the chuck by air pressure of approximately 8 bar. The next pallet is then clicked into position. Research shows that, from another perspective described by Rashid et al, [16], palletised work-holding systems also offer a unique opportunity to address the problem of vibration control for milling operations.

Using this setup technology, five sides of the part are accessible to the machine tool cutter. Clamping is achieved using a ball lock mechanism. The lock is positive. Opening of the chuck is pneumatically actuated and is designed to be fail-safe. The chuck closes 
mechanically; therefore, if the air supply is cut off, the chuck remains securely clamped. It takes only a few seconds to remove a pallet and replace it with the next that has been preset during the machine's operation time. In this way, more time is saved by the elimination of the need to re-establish a datum for each part. Locating and securing pallets, and then unloading finished parts, takes a significant amount of setup time. Palletising parts off-line within machining time, and then positioning and securing them in common chucks, achieves a marked reduction in setup time. In the developed world it is common practice for operators to be assigned to more than one machine. In the developing world, however, this practice is rare, which allows for the possibility of using machining time for setup without any cost implication.

With the increasing pressure of competition, demands made on flexibility in the workshops are extreme. The production of one-off parts and small series is under particular cost pressure. Especially in this area, many plants still have a large cost reduction potential. This could be put to good use, both directly to enhance competitiveness, and also indirectly by releasing capital intensive 5 -axis capacity.

\section{RESULTS}

After experimentation and a time study, the following results were recorded. The machining time of the current process was compared with the proposed (improved) process in terms of the first-off machined parts and machining time of all the parts.

The bar charts below give a graphical representation of the current process compared with the proposed (improved) process. As indicated in figure 6, the machining of the missile wing comprised eight different operations. From the figure it can be seen that the time taken to set up the first part of the batch for each operation, and the time necessary to do a quality inspection, are also reduced. These results are due to the standard pallet work-holding method being used for all operations. This standardisation also gave the machine shop the ability to interchange work between machines, as well as shifts, efficiently. The machining time is thus reduced, as shown per operation.

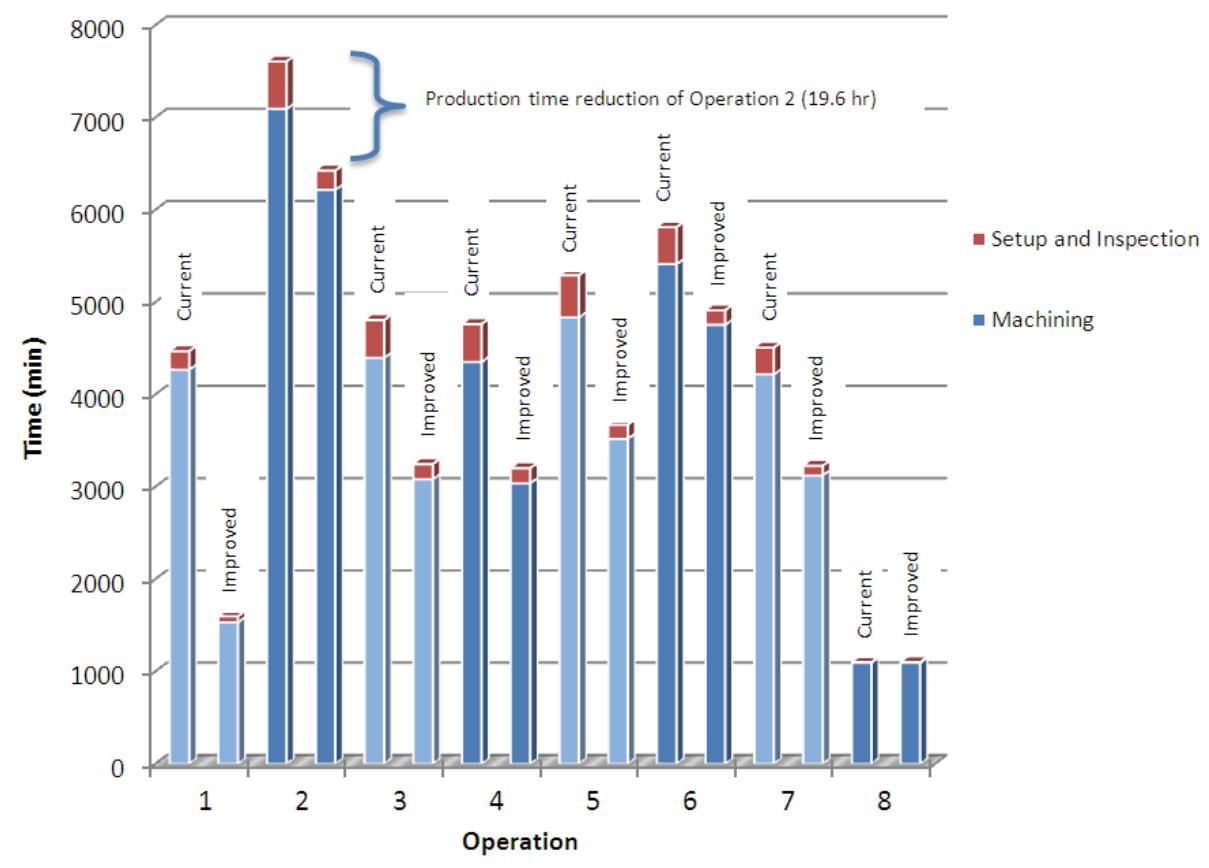

Figure 6: A comparison between the old and the improved process for the individual machining times for each operation in the process 
From the figures it is evident that the pallet work-holding technique significantly decreases the time taken physically to do the setup and inspection of each operation, and decreases the machining time for each operation. This improved process leads to a saving of 183 production hours, as shown in figure 7.
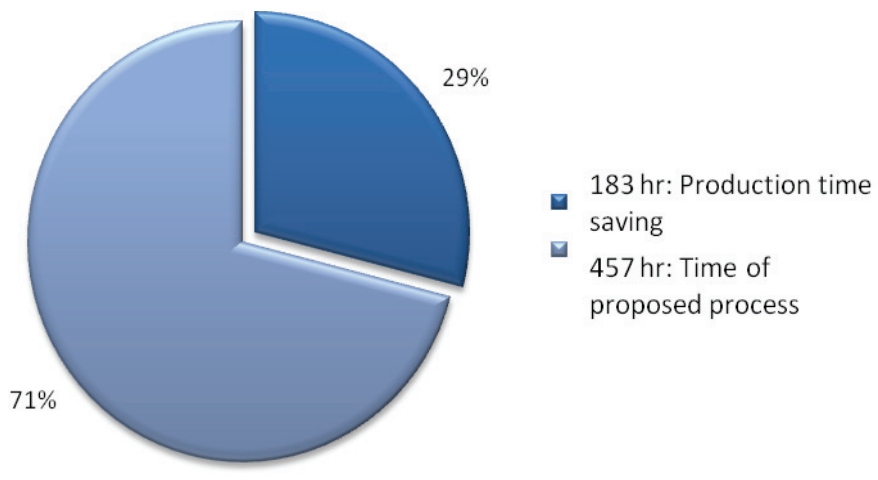

Figure 7: Capacity occupancy and lead time (production time) reduction for proposed pallet process (full circle of 640 hours represents the existing process)

This reduction in production time represents a saving of 20.3 working shifts of 9 hours each.

\subsection{Return on investment}

It is critical for similar enterprises to know how the expected investment compares with the lead times and capacity occupancy. If the 3 -axis milling machine that was investigated is occupied with the same type of work, the following calculation of return on investment (ROI) is applicable. It could be argued that the machine could do simple 3-axis work for a significant percentage of its time, in which case this projection of ROI will not be as favourable. For the ROI calculation the conservative assumption was made that similar 5axis work would be performed on the 3 -axis machine for $50 \%$ of the time. The owner of the machining company stated that his objective was to increase high complexity work and to decrease the percentage of simple machining work. The effect of this policy is already reflected in the fact that utilisation of the 5 axis machine has grown to 7 days a week, 24 hours a day. The ROI is expressed in terms of payback period.

Investment: $\quad$ Chuck: $€ 4,400$, Pallet $€ 400 \times 3$.

Expenses: $\quad 3$-axis milling machine operates at $€ 24 / \mathrm{hr}$ with $50 \%$ of work to be similar.

Savings: $\quad$ Similar projects can be completed $29 \%$ earlier, resulting in significant savings.

Payback period:

Using $P=A[(1+i) n-1 / i(1+i) n],[17]$ and the cash flow diagram below [Figure 9] the payback period was calculated.

where

$\mathrm{P}$ (Present value) $\quad=€ 5,600$ loaned at $\mathrm{i}=14 \%$ (annually)

A (Annual savings) $\quad=€ 24 / \mathrm{hr} \times 50 \% \times 29 \% \times 9(\mathrm{hr} /$ day) $\times 5$ (days/week) $\times 4.2$ (weeks)

$=€ 657.72$ savings per month 


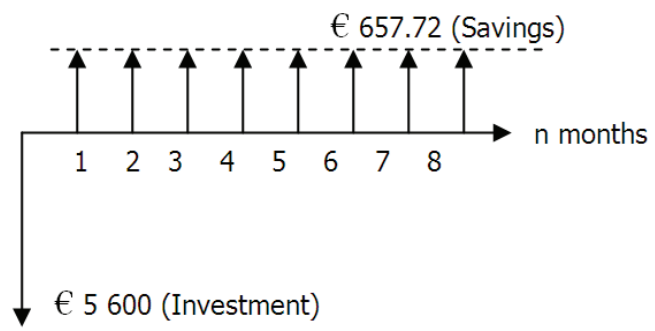

Figure 8: Cash flow diagram of investment

Using a discrete cash flow table [17] with a 1\% discrete interest rate, the payback period is 186 days or 8.85 months, as illustrated in figure 9 .

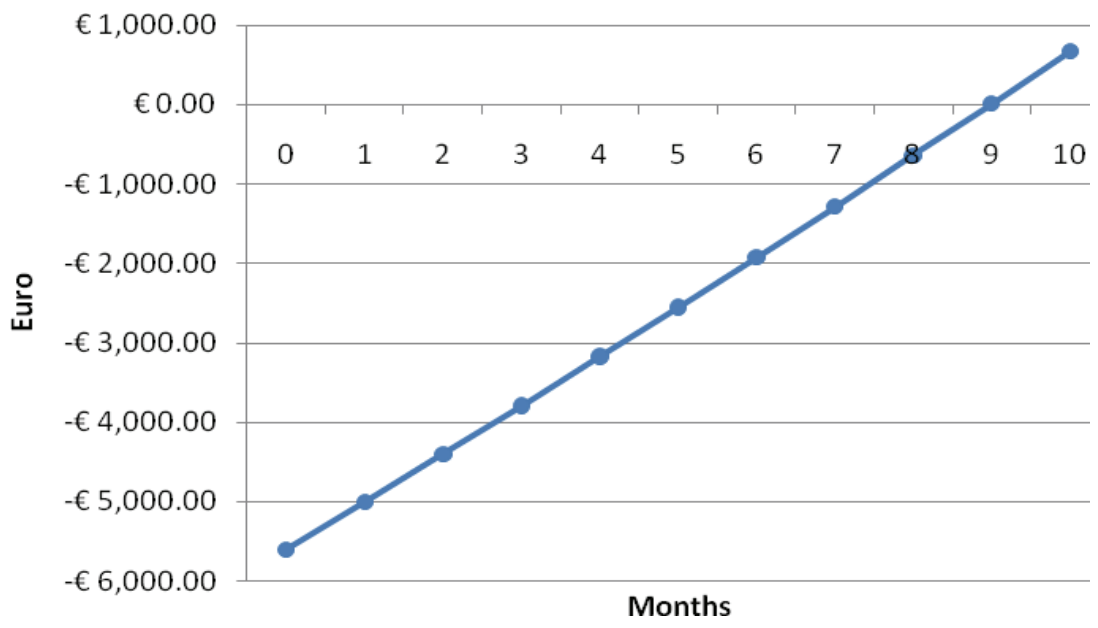

Figure 9: Payback period for initial investment (ROI progression - year 1)

Hours of work per year: $\quad=2,250 \mathrm{hr}(250$ days $\times 9 \mathrm{hrs})$

Value of freed capacity per year: $=€ 7,830.00(50 \% \times € 24 \times 2,250 \mathrm{hr} \times 29 \%)$

According to the calculation above, the company is saving $€ 7,830.00$ per year by investing in this work-holding system.

\subsection{Discussion}

Although it is clear that the proposed pallet process shows a significant reduction in time, as well as enabling 5 -axis work on a 3 -axis machine, there are several other benefits that the palletised process introduces.

In the machining sector, standards of equipment makers have mostly been kept as brand specific specifications. Reluctance to establish compatibility between unlike machines and accessories carries over into both hardware and software. Therefore, standardisation becomes the responsibility of the individual company. Once the work piece has been palletised, it is standardised and can be placed securely on any machine equipped with a compatible receiver or chuck. With this standard work-holding method, the operator easily reduces his first-off setup times and also minimises the total time per operation. This standardisation gives the machine shop the ability to interchange work efficiently between machines and shifts. The design of the pallet and its chuck assures consistent placement of 
a work piece in a machine tool. These supplementary factors on their own present a strong case for using a palletising system.

However, it is the modularity of the proposed process that gives the machine shop a method of dealing with various applications in a straightforward way. Modularity is important for processing different sizes and shapes of work piece blanks. The chuck is designed to accept a large selection of pallet configurations.

\section{CONCLUSION}

The implementation of the palletising system leads to a great reduction in production time. The time study compared the current process against the proposed improved process. The improved process decreases the production time of 640 hours by 183 hours. This represents a saving of 20.3 working shifts of 9 hours each. The current process requires 71 working shifts, while the proposed process would require only 50.7 working shifts, a $28.6 \%$ saving in production time. The company can therefore supply the finished products to their clients 20.3 days earlier than originally planned. This amounts to a saving of $€ 7,830.00$ per year, achieved by investing in the work-holding system. Seen from an investment perspective, the capital expenditure will be recovered after a payback period of about 9 months.

The pallet system significantly reduces the setup and changeover times, freeing production capacity and reducing lead time. If the pallet system is deployed on a larger scale by the company it will contribute significantly to flexibility. The project was chosen for its potential to free production capacity and reduce lead time. There is little doubt that the level of improvement would not be sustained if the system were deployed on a larger scale. It does, however, yield improvements that will make a significant contribution to competitiveness. The next step would be to select follow-up tasks that can make use of the technology, and gradually implement the technology on a larger scale to keep the ROI on the pallet equipment at a profitable level.

The 3-axis technique using palletised work-holding is both technically feasible and economically viable to machine flat surface aerospace components that would normally be machined on simultaneous 5 -axis machines in the developed world.

\section{ACKNOWLEDGEMENTS}

Mr Norbert Leicher, Daliff Precision Engineering (Pty) Ltd, for hosting the study.

Mr Zaid Fakier, Daliff Precision Engineering (Pty) Ltd, for sharing his technical expertise.

Mr Aubrey Simon and Mr Werner Lombard, Rheinmetall Denel Systems (Western Cape), for permission to use their product as the test bed for the concept study.

\section{REFERENCES}

[1] Byrne, G., Dornfeld, D. \& Denkena, B. 2003. Advancing cutting technology, Keynote Papers STC “C”, Annals of CIRP, 52 (2), pp. 483-508.

[2] Nagarjunaa, N., Mahesh, O. \& Rajagopal, K. 2006. A heuristic based on multi-stage programming approach for machine-loading problem in a flexible manufacturing system, Robotics and Computer-Integrated Manufacturing 22, pp. 342-352.

[3] Die Deutsche Werkzeugmaschinenindustrie. 2001. VDW. Frankfurt/Main. January 2002.

[4] Viswanadham, N. \& Narahari Y. 1992. Performance modeling of automated manufacturing systems. India: Prentice-Hall.

[5] Fellers, William O. \& Hunt, William W. 2001. Manufacturing processes for technology. $2^{\text {nd }}$ edition. Prentice Hall. 
[6] Shirinzadeh, B. 1995. Flexible and automated workholding systems, Industrial Robot, Vol. 22 No. 2, pp. 29-34. MCB University Press.

[7] Choi, D.S., Lee, S.H., Shin, B.S., Whang, K.H., Yoon, K.K. \& Sanjay, E.S. 2001. A new rapid prototyping system using universal automated fixturing with feature-based CAD/CAM, Journal of Materials Processing Technology, 113, pp. 285-290.

[8] Grundler, E. 2002. Weg vom einfachen Drehteil - hin zur Komplettbearbeitung, VDIZ Integrierte Produktion. 144/11-12:29-31.

[9] Koste, L.L. \& Malhotra, M.K. 1999. A theoretical framework for analyzing the dimensions of manufacturing flexibility, Journal of Operations Management 18, pp. 75-93.

[10] Sarker, B.R., Krishnamurthy, S. \& Kuthethur, S.G. 1994. A survey and critical review of flexibility measures in manufacturing systems, Production Planning and Control 5 (6), pp.512-523.

[11] Chen, I.J. \& Chung, C.H. 1996. An examination of flexibility measurements and performance of flexible manufacturing systems, International Journal of Production Research 34, pp. 379-394.

[12] Wahab, M.I.M. 2005. Measuring machine and product mix flexibilities of a manufacturing system, International Journal of Production Research 43, pp. 37733786.

[13] Groover, Mikell P. 2001. Automation, production systems, and computer-integrated manufacturing. $2^{\text {nd }}$ edition, Prentice Hall.

[14] Weck, M. 2002. Werkzeugmaschinen für die Produktion von morgen im Spannungsfeld, Proceedings of the Aachener Werkzeugmaschinen Kolloquium 2002, pp. 373-409.

[15] Theodorou, P. 1996. The restructuring of production in SMEs: The strategy of manufacturing flexibility. Management of SMEs. ITE: University Press of Creta. pp. 47-56.

[16] Rashid, A. Mihai \& Nicolescu, C. 2006. Active vibration control in palletized workholding systems for milling, International Journal of Machine Tools \& Manufacture 46, pp. 1626-1636.

[17] Blank, L. \& Tarquin, A. 1985. Engineering economy. $2^{\text {nd }}$ edition, McGraw-Hill. 